atric symptoms in patients of Asian origin, possibly because the patients are more likely to present symptoms somatically. ${ }^{18}$ Another found that this failure applied to anxiety but not to depression. ${ }^{19}$

An alternative explanation is that general practitioners recognise signs of mental illness but think it inappropriate to treat or refer patients and leave this to other agencies. Such behaviour may not be confined to general practitioners born and trained in Britain. Those trained in the Indian subcontinent and practising in Britain are less likely than their British counterparts to think it appropriate for patients to consult with family problems and may overtly or tacitly discourage patients with such problems from attending. ${ }^{20}$ Psychiatry has low status within medical education in India, ${ }^{21}$ and one study has shown that general practitioners in India can identify only a quarter of probable cases of psychiatric morbidity. ${ }^{22}$

A widespread view is that much illness, particularly mental illness, remains managed within the Asian family. No attempt has been made to test this idea, although the belief affects action: general practitioners, for example, are inhibited from referring Asian patients to district nursing services. ${ }^{23}$ Nevertheless, some evidence supports the idea. Bengali children referred to a child psychiatry service in east London presented a narrower range of problems than white children. ${ }^{10}$ This may indicate Asian patients' unwillingness to proceed to further treatment, especially that requiring admission to hospital, which is seen as a mark of serious illness. ${ }^{64}{ }^{25}$ Referral to a psychiatrist may affect marriage prospects. ${ }^{26}$

Some patients may be shielded from medical care more than others. Studies of general practitioner consultation rates suggest that contact is particularly inhibited for women, ${ }^{7-9}$ who seem to be uncertain of expectations in a doctor-patient relationship, ${ }^{27}$ especially when the general practitioner is a man. ${ }^{28}$ Many requests to a phone-in advice service for ethnic minorities were from women with severe life crises who were seeking the help of a woman doctor..$^{29}$

An additional reason for low presentation rates for mental illness is that ideas of psychological causation of illness are poorly understood within Asian cultures. ${ }^{2430} 31$ Moreover, treatment by general practitioners for conditions such as depression and anxiety has become commonplace only in the last generation, and it is hardly surprising if older Asians behave differently in seeking help for such conditions. ${ }^{32}$ Patients may sidestep conventional medical services and prefer to approach hakims or other alternative healers, but there is little evidence that this happens on a major scale. ${ }^{233} 34$ Mentally ill British Asians may, however, travel to Asia for treatment: almost a quarter of those from one sample who had visited the subcontinent had visited an Asian healer while they were there. ${ }^{33}$

Although British Asians may thus show both genuinely low rates of mental illness and a tendency to underreport mental illness, their prevalence of mental illness will probably gradually reach national levels, both overall and for particular diagnoses. In the meantime Asian patients may need encouragement to express their emotional problems in psychological terms and doctors need to develop a greater sensitivity in recognising them.

Senior Research Fellow,

Newham Health Authority,

London E13 0DZ

1 London M. Mental illness among ethnic minorities in the UK. Br f Psychiatry 1986;149:265-73. 2 Ineichen B. The mental health of Asians in Britain: a research note. New Community 1987;14: $136-41$

3 Leff J. Psychiatry around the globe: a transcultural view. 2nd ed. London: Gaskell/Royal College of Psychiatrists, 1988.

4 Brewin C. Explaining the lower rates of psychiatric treatment among Asian immigrants to the United Kingdom: a preliminary study. Soc Psychiatry 1980;15:17-9.
Mahmud S. Life stress and symptoms: a comparative study of Pakistani and English women. In: Dent H, ed. Clinical psychology: research and development. London: Croom Helm, 1987:111-7. Blakemore K. Ethnicity, self-reported illness and use of medical services by the elderly. Postgrad Med f 1983;59:668-70.

Murray J, Williams P. Self-reported illness and general practice consultations in Asian born and British born residents of West London. Soc Psychiatry 1986;21:139-45.

Gillam SJ, Jarman B, White P, Law R. Ethnic differences in consultation rates in urban general practice. BrMed f 1989;299:958-60.

Balarajan R, Yuen P, Raleigh V. Ethnic differences in general practice consultations. Br Med $\mathcal{F}$ 1989;299:958-60.

10 Stern G, Cottrell D, Holmes J. Patterns of attendance of child psychiatry out-patients with special reference to Asian families. Br I Psychiatry 1990;156:384-7.

11 Hill D. Personality factors among adolescents in ethnic minority groups. Educational Studies 1975;1:43-54.

12 Karlarackal AM, Herbert M. The happiness of Indian immigrant children. New Society $1976 \mathrm{Feb}$ 26:422-4

3 Cochrane R, Stopes-Roe M. Psychological and social adjustment of Asian immigrants in Britain: a community survey. Soc Psychiatry 1977;12:195-206.

14 Cochrane R, Stopes-Roe M. Psychological symptom levels in Indian immigrants to England: a comparison with native English. Psychol Med 1981;11:319-27.

15 Cochrane R. Social creation of mental illness. London: Longman, 1983.

16 Ebden P, Carey OJ, Harrison B, Bhatt A. The bilingual consultation. Lancet 1988;i:347:

7 Stevens KA, Fletcher RF. Communicating with Asian patients. Br Med f 1989;299:905-6.

$8 \mathrm{Bal} \mathrm{SS}$. Psychological symptomatology and health beliefs of Asian patients. In: Dent $\mathrm{H}$, ed. Clinical psychology: research and development. London: Croom Helm, 1987:101-10.

19 Nayani $S$. The evaluation of psychiatric illness in Asian patients by the hospital anxiety depression scale. Br f Psychiatry 1989;155:545-7.

20 Cartwright A, Anderson R. General practice revisited. London: Tavistock, 1981.

21 Cohen D. Forgotten millions. London: Paladin, 1988.

21 Cohen D. Forgotten millions. London: Paladin, 1988.

Shamasundar C, Murthy SK, Prakash OM, Prabhakar N, Krishna DKS. Psychiatric morbidity in general practice. BrMed f 1986;292:1713-5.

23 Badger F, Atkin K, Griffiths R. Why don't general practitioners refer their disabled Asian patients to district nurses? Health Trends 1989;21:31-2.

24 Henley A. Asian patients in hospital and at home. London: King's Fund, 1979.

25 Rack P. Race, culture and mental disorder. London: Tavistock, 1982.

6 Qureshi B. Transcultural medicine: dealing with patients from different cultures. Dordrecht: Kluwer, 1988.

27 Donovan J. Black people's health: a different approach. In: Rathwell T, Phillips D, eds. Health, race and ethnicity. London: Croom Helm, 1986:137-74.

28 Currer C. Pathan mothers in Bradford. Coventry: University of Warwick, 1983.

29 Webb P. Health problems of London's Asians and Afro-Caribbeans. Health Visitor 1981:54:141-7.

Skultans V. Psychiatric community care: a Matarastrian example. Psychol Med 1986;16:499-501. mental disorder among Indian patients: preliminary report of work in progress. Soc Sci Med
mestist mental disorder

32 Manning M. Transcultural psychiatry. Community Care 1979;248:19-21.

33 Bhopal RS. The inter-relationship of folk, traditional and Western medicine within an Asian community in Britain. Soc Sci Med 1986;22:99-105.

34 Johnson MRD. Inner city residents, ethnic minorities and primary health care in the West Midlands. In: Rathwell T, Phillips D, eds. Health, race and ethnicity. London: Croom Helm, 1986;192-212.

\section{Atherosclerotic renovascular disease}

\section{Remediable cause of renal failure in the elderly}

Renovascular disease has long been recognised as a cause of hypertension and renal impairment, ${ }^{12}$ but the syndrome consists of two quite different conditions with few common features.

A young woman with renal artery stenosis as the cause of her hypertension will most commonly have an artery that has been narrowed by medial hyperplasia. The less commonly recognised variant is the older patient with widespread vascular disease and hypertension in whom the renal artery or arteries have been narrowed by atherosclerotic disease. Atherosclerotic renal artery stenosis has a high likelihood of progression to occlusion and a $40 \%$ probability of development of contralateral stenosis within four years. ${ }^{34}$ In contrast to medial hyperplasia, therefore, atherosclerotic renovascular disease often presents when a significant stenosis has developed in a solitary kidney, the other kidney having previously and silently lost function owing to renal artery occlusion. ${ }^{5}$

Recent studies have confirmed the high prevalence of atherosclerotic renal artery stenosis in the elderly population. In one study 39 of 106 patients presenting with hypertension and renal impairment and in another $14 \%$ of patients over the age of 50 presenting with advanced renal failure had renal artery disease as the underlying cause.$^{56}$ Furthermore, half of the patients with advanced renal failure were being treated with an angiotensin converting enzyme inhibitor when renal failure developed. The action of this group of drugs in precipitating acute renal failure in patients with bilateral 
renal artery stenoses or renal artery stenosis in a solitary kidney is now well established. ${ }^{25}$ This ability to unmask significant renal artery stenosis when combined with ${ }^{99} \mathrm{Tc}$ diethylenetriaminepentaacetic acid scanning may prove to be a useful diagnostic tool. ${ }^{7}$ Angiography remains the diagnostic investigation of choice, however, but in this group of high risk patients it may be associated with substantial morbidity and, indeed, mortality.

Any discussion of treatment options must take account of the fact that these patients invariably have advanced generalised atherosclerotic disease, so that treatment of any kind carries a high risk. ${ }^{3}$ Revascularisation can be achieved by percutaneous transluminal angioplasty or by reconstructive vascular surgery. Angioplasty gives satisfactory results in medial hyperplasia but has proved disappointing in atherosclerotic lesions, particularly the most frequently occurring one, which is at the ostium of the renal artery. ${ }^{28}$ Furthermore, even after successful dilatation there may be permanent damage to the renal parenchyma from injection of contrast medium into the ischaemic kidney during the procedure. ${ }^{9}$

Reconstructive surgery for preserving renal function has been performed for many years by using several operative approaches. ${ }^{10-13}$ Initially, mortality was high, but more recently the Cleveland Clinic has reported a series of 51 patients with no perioperative mortality-but in whom any coronary or carotid lesions were repaired before the renal surgery. ${ }^{1415}$ An attractive alternative operative approach is by revascularisation from the hepatic or splenic arteries, thus avoiding aortic cross clamping. Good success rates with low morbidity and mortality have been reported. ${ }^{16}$

Surgery is mostly carried out in patients with renal artery stenosis, but renal function that has been lost for weeks owing to complete occlusion may also be retrieved by reconstruction. ${ }^{17}$ Nor should a history of pulmonary oedema be regarded as a contraindication for revascularisation by either angioplasty or surgery; there seems to be a specific association between renal vascular disease and pulmonary oedema, which may in fact be cured by this approach. ${ }^{18}$ Revascularisation is therefore a most reasonable goal in this group of patients, who are generally at high risk and in whom renal dialysis is not an attractive or feasible alternative. The excellent results cited have, however, been reported from centres of excellence with a high throughflow of these patients, and common sense suggests that morbidity and mortality will be much higher in centres with less experience and skill.

Management policies seem to vary, but patients with mild to moderate renal failure are generally managed conservatively with frequent monitoring of renal function. Revascularisation is recommended for those with severe or rapidly progressing renal failure or if there is pulmonary oedema. The place of angioplasty is controversial, but our experience and that of others has led us to advocate angioplasty only for non-ostial stenoses. Unfortunately, we find that ostial lesions are by far the most common and in these cases recommend surgical revascularisation from the splenic or hepatic arteries.

Clearly the recent introduction of angiotensin converting enzyme inhibitors has led to the more frequent recognition of atherosclerotic renovascular disease as a common clinical entity-and a challenging management problem in our growing elderly population.

J E SCOBLE

Senior Registrar, Renal Unit

G HAMILTON

Royal Free Hospital and School of Medicine, Consultant Surgeon

London NW3 2QG
1 Vaughan ED. Renovascular hypertension. Kidney Int 1985;27:811-27.

Jacobson HR. Ischemic renal disease: an overlooked clinical entity? Kidney Int 1988;34:729-43. Wollenweber J, Sheps SG, Davis GD. Clinical course of atherosclerotic renovascular disease. Am f Med 1968:21:60-70.

Schreiber MJ, Pohl MA, Novick AC. The natural history of atherosclerotic and fibrous renal artery disease. Urol Clin North Am 1984;11:383-92.

Scoble JE, Maher ER, Hamilton G, Dick R, Sweny P, Moorhead JF. Atherosclerotic renovascular disease causing renal impairment-a case for treatment. Clin Nephrol 1989;31:119-22.

6 Ying CY, Tifft CP, Garvas H, Chobanian AV. Renal revascularisation in the azotemic hypertensive patient resistant to therapy. N Engl f Med 1984;311:1070-5.

Maher ER, Otham S, Frankel AH, Sweny P, Moorhead JF, Hilson AJW. Captopril-enhanced ${ }^{* M}$ Tc DTPA scintigraphy in the detection of renal artery stenosis. Nephrol Dial Transplan 1988:3:608-11.

Dean RH, Callis JT, Smith BM, Meacham PW. Failed percutaneous transluminal renal angioplasty: experience with lesions requiring operative intervention. $\mathcal{F}$ Vasc Surg 1987;6:301-7. Weibull $\mathrm{H}$, Tornqvist $\mathrm{C}$, Bergqvist $\mathrm{D}$, et al. Reversible renal insufficiency after percutaneou transluminal angioplasty (PTA) of renal artery stenosis. Acta Chir Scand 1984; 150:295-300.

10 Sheil AGR, May J, Stokes GS, Johnson JR, Tiller DJ, Stewart JH. Reversal of renal failure by revascularisation of kidneys with thrombosed renal arteries. Lancet 1973;ii:865-6.

1 Wasser WG, Krakoff LR, Haimov M, Glabman S, Mitty HA. Restoration of renal function after bilateral renal artery occlusion. Arch Intern Med 1981;141:1647-51.

2 Baird RJ, Yendt ER, Firor WB. Anuria due to acute occlusion of the artery to a solitary kidney. N Engl f Med 1965;272:1012-4.

Morris GC, DeBakey ME, Cooley DA. Surgical treatment of renal failure of renovascular origin. IAMA 1962;182:113-6.

4 Bengtsson U, Bergentz S-E, Norback B. Surgical treatment of renal artery stenosis with impending uremia. Clin Nephrol 1974;2:222-9.

15 Novick AC, Pohl MA, Schreiber M, Gifford RY, Vidt DG. Revascularisation for preservation of renal function in patients with atherosclerotic renovascular disease. F Urol 1983;129:907-11.

6 Moncure AC, Brewster DC, Darling RC, Atnip RG, Newton WD, Abbott WM. Use of the spleni and hepatic arteries for renal revascularisation. F Vasc Surg 1986;3:196-203.

17 Bergentz S-E, Bergqvist D, Weibull H. Changing concepts in renovascular surgery. Br f Surg 1989;76:429-30

18 Pickering TG, Devereux RB, James GD, et al. Recurrent pulmonary oedema in hypertension due to bilateral renal artery stenosis: treatment by angioplasty or surgical revascularisation. Lancet $1988 ;$ ii: $551-2$

\section{Oocyte donation}

\section{Ethical rather than practical problems need to be solved}

Oocyte donation is a simple technique, ${ }^{1}$ newer than semen or embryo donation, ${ }^{2-4}$ that offers a chance of pregnancy to selected infertile women. Despite its simplicity, however, it is underused, partly because oocytes are inherently harder to donate than semen, and thus donors are harder to find, and partly because oocyte donation lies in a legal grey area. Furthermore, some exciting recent work on primordial follicle donation may soon make oocyte donation unnecessary. But in the meantime it is not being offered to many women who could benefit.

The main group of women who can benefit are those with autoimmune or idiopathic ovarian failure (about $1 \%$ of infertile women)..$^{5}$ Others include women with gonadal dysgenesis (1 in 10000 births) and those whose ovaries have been put out of action by surgery, radiotherapy, or chemotherapy. ${ }^{6-12}$ Oocyte donation may also help older women with reduced oocyte quality, and rare uses are to circumvent genetic disease with $\mathrm{X}$ linked conditions and for couples refusing donor semen. Oocyte donation is not, however, needed for in vitro fertilisation in women in whom pelvic adhesions prevent laparoscopy; their oocytes may be recovered from the vagina. ${ }^{13}$

Clinically, oocyte donation is simple..$^{6-121415}$ Steroid regimens are now well established for endometrial control, ${ }^{14-16}$ and have already proved successful for the transfer of frozenthawed embryos ${ }^{17}$ Most centres stimulate the development of several follicles in the donor, synchronising cycles to allow embryo transfer during the recipient's "implantation window." Treatment with gonadotrophin releasing hormone analogues increases the number of oocytes, ${ }^{18}$ and when the long cycle protocol is used stimulation with gonadotrophin can be delayed until the recipient's cycle synchronises. Alternatively, the luteal phase of either woman can be lengthened with progestogens. ${ }^{1920}$ The oocytes may then be 